\title{
Alternative surgical approach for inflatable penile prosthesis removal
}

\author{
Abdalla Alhammadi ${ }^{1}$, Maher Abdessater ${ }^{2^{*}}$, Abdulmajeed Althobity ${ }^{3}$, Anthony Kanbar ${ }^{3}$, Walid Sleiman ${ }^{4}$, \\ Bertrand Guillonneau', Ahmed Zugail ${ }^{1}$ and Sebastien Beley ${ }^{1,3}$
}

\begin{abstract}
Background: The Inflatable penile prostheses (IPP) are used as definitive treatment for severe erectile dysfunction. Removal of an IPP can be challenging, especially for the non-andrologists and junior urologists. The classic penoscrotal incision for explanation can disrupt anatomy, which increases the risk of complications and makes future re-implantation difficult. This article aims to describe a simple surgical method for the removal of IPP, which avoids the penoscrotal incision and reduces the risk of urethral damage and additional fibrosis.
\end{abstract}

Material and methods: Between November 2015 and February 2019, 15 patients underwent IPP removal using the same technique. Multiple incisions were performed directly over each component of the IPP for their removal. Four incisions of $2 \mathrm{~cm}$ each were made at the following sites: one incision on both sides of the ventral base of the penis, one inguinal incision, and one scrotal incision. Each incision provides direct access to one component of the IPP (cylinders, reservoir, and pump).

Results: The mean duration of the surgery was 41 min (between 35 and $48 \mathrm{~min}$ ). All procedures were completed successfully with a smooth course. None of the patients had any residual component of the IPP at the time of surgery. Neither complications (urethral or intestinal injury) nor excessive bleeding $(>100 \mathrm{~mL}$ ) were documented in all patients.

Conclusion: Our approach provides direct exposure of all components of the IPP. It reduces the risk of urethral iatrogenic injury and the local fibrosis (which is greater with the penoscrotal incision) that may impair future reinsertion of IPP. It is simple, safe, reproducible and easy to be performed by junior or unexperienced urologists in urgent cases.

Resume: Contexte: Les implants péniens hydrauliques (IPH) constituent le traitement définitif des dysfonctions érectiles. Le retrait de ces prothèses peut être difficile, surtout pour les jeunes urologues. L'incision classique pénoscrotale est. peu anatomique. Elle est. associée à un risque de plaies urétrales et de fibrose pouvant limiter l'insertion ultérieure de nouvelles prothèses. Nous présentons dans cet article une méthode alternative simple pour le retrait des IPH qui permet d'éviter l'incision péno-scrotale et les risques qui s'y associent.

Matériel et Méthodes: Entre novembre 2015 et février 2019, 15 patients ont été opérés pour extraction d'IPH infectés, en utilisant la même technique chirurgicale. Une incision de $2 \mathrm{~cm}$ est. réalisée en face de chaque élément de l'IPH pour permettre son extraction: une incision scrotale, une autre inguinale et une de chaque côté de la base ventrale du pénis.

(Continued on next page)

\footnotetext{
* Correspondence: maher.abdessater@gmail.com

²Department of Urology and Renal Transplantation, APHP- La pitié

Salpêtrière University Hospital, Paris, France

Full list of author information is available at the end of the article
}

(c) The Author(s). 2020 Open Access This article is licensed under a Creative Commons Attribution 4.0 International License, which permits use, sharing, adaptation, distribution and reproduction in any medium or format, as long as you give appropriate credit to the original author(s) and the source, provide a link to the Creative Commons licence, and indicate if changes were made. The images or other third party material in this article are included in the article's Creative Commons licence, unless indicated otherwise in a credit line to the material. If material is not included in the article's Creative Commons licence and your intended use is not permitted by statutory regulation or exceeds the permitted use, you will need to obtain permission directly from the copyright holder. To view a copy of this licence, visit http://creativecommons.org/licenses/by/4.0/ The Creative Commons Public Domain Dedication waiver (http://creativecommons.org/publicdomain/zero/1.0/) applies to the data made available in this article, unless otherwise stated in a credit line to the data. 
(Continued from previous page)

Résultats: La durée moyenne de l'intervention était de 41 min (entre 35 et 48 min). Toutes les interventions ont été bien tolérées. Les éléments des IPH ont été retirés sans fragments résiduels. Aucune complication n’a été notée.

Conclusion: L'approche décrite permet l'exposition directe des composantes des IPH. Elle permet la réduction du risque des lésions urétrales iatrogène et de fibrose ultérieure. Celle-ci est. plus fréquente avec l'incision péno-scrotale et peut limiter l'éventuelle insertion de nouveaux implants. Notre technique est. reproductible et simple pour être appliquée sans danger par les jeunes urologues peu expérimentés.

Mots-clés: Implants peniens hydrauliques, Retrait , Approche, Infection

\section{Introduction}

Erectile dysfunction (ED) is a disorder that affects 152 million men worldwide, and this number is estimated to reach 322 million by the year 2025 [1]. Inflatable penile prostheses (IPP) are used as a definitive treatment for severe ED after the failure of conservative medical treatment, or when the latter is contraindicated [2]. The implant is very effective with high levels of patient and partner satisfaction. Infection, hematoma, corporal fibrosis or perforation, erosion, urethral injury, and glandular ischemia are reported in 5\% of patients after IPP implantation [3]. The rate of device mechanical failure is around $15 \%$ at 5 years. The infection of the device is rare (1-3\%), but devastating when happening. The actual low rate of infection is the result of the use of antibioticcoated devices, implementation of prophylactic antibiotic regimens, improvement of skin preparations, and the use of the "no-touch" technique during implantation [4]. In IPP infections, the removal of all the components of the device is recommended. The extraction of the reservoir is surgically challenging due to its anatomical location. The classic penoscrotal incision for explantation may lead to the injury of the urethra and the disruption of the anatomical structures and may damage the surrounding tissues, predisposing to fibrosis and making future re-implantation difficult [3].

We aim by this article, to describe a simple surgical technique for the removal of penile prostheses, that avoids the penoscrotal incision and its associated complications. It was developed by an expert andrological team with 10 years' experience in the domain and became the standard technique at our institution.

\section{Material and methods}

\section{Patients selection}

Between November 2015 and February 2019, 15 patients underwent IPP removal using the same technique, by the same surgical team. Indications for removal were divided into infectious in 12 patients $(80 \%)$, and noninfectious in 3 cases $(20 \%)$ related to an unsatisfactory result, patient discomfort or device erosion. The former group had the prosthesis removed between 2 and 36 days from the onset of infection after the failure of conservative treatment. Voluntary removal of the device was performed 10 days after its implantation in the three patients. The demographic characteristics of the patients are detailed in Table 1. Two types of IPP were identified: Titan $^{\odot}$ Touch (Coloplast Group, Humlebaek, Denmark) in 11 patients $(73 \%)$ and Titan ${ }^{\circ}$ OTR (Coloplast Group, Humlebaek, Denmark) in 4 patients (27\%). The causes of ED that lead to the implantation of the IPP are detailed in Table 2.

\section{Surgical technique}

After obtaining the patient's consent, general or spinal anesthesia is applied. The patient is placed in a supine position, and an indwelling urinary catheter is inserted. The skin is shaved and prepped with an alcoholic-iodine solution. A $2 \mathrm{~cm}$ transverse incision is performed at each side at the ventral base of the penis (Fig. 1a). A corporotomy is done using a diathermy pencil, and a $2-0$ absorbable stay suture is placed on each side of the corporotomy (Fig. 1b). The cylinders of the IPP are exposed and extracted using a Kelly clamp (Fig. 1c). Their rear tips are sent to the microbiology laboratory for culture. Another $2 \mathrm{~cm}$ scrotal incision is made directly over the pump. The optimal goal is to remove the pump with its pseudo-capsule (Fig. 2). A clamp is placed on the tube connecting to the reservoir and tugged to facilitate finding the reservoir. A transverse inguinal incision is carried out over the reservoir to allow its exposure and removal (Fig. 3). After the removal of all the components of the IPP, a culture swab is taken from the infected tissues. Before closing the wounds, tissues are irrigated with a mixture of iodine, hydrogen peroxide and normal saline using a $60 \mathrm{ml}$ catheter tip syringe to wash out infected debris. Two corrugated silicone sheet drains (Delbet drains) are placed in the wounds: one in the inguinal incision and the other in the scrotal one. The

Table 1 Patients' demographic data

\begin{tabular}{lll}
\hline Variable & Range & Mean \\
\hline Age (years) & $49-71$ & 59.53 \\
Body mass index $\left(\mathrm{kg} / \mathrm{m}^{2}\right)$ & $21-35$ & 28 \\
Time between implantation and removal (months) & $0.3-54$ & 22.77 \\
\hline
\end{tabular}


Table 2 Causes of erectile dysfunction leading to penile prosthesis insertion

\begin{tabular}{lll}
\hline Cause & $\mathrm{N}$ & Percentage \\
\hline Radical prostatectomy & 4 & $27 \%$ \\
Pelvic radiotherapy & 3 & $20 \%$ \\
Diabetes mellitus & 2 & $13 \%$ \\
Radical prostatectomy + Diabetes mellitus & 2 & $13 \%$ \\
Radical cystoprostatectomy & 2 & $13 \%$ \\
Radical prostatectomy + Pelvic radiotherapy & 1 & $7 \%$ \\
Colectomy & 1 & $7 \%$ \\
Total & 15 & $100 \%$ \\
\hline
\end{tabular}

drains are fixed to the skin using braided nonabsorbable sutures. Finally, the corporotomy edges are closed using monofilament absorbable sutures and the skin is approximated using simple non-absorbable monofilament sutures.

\section{Post-operative management and follow-up}

Broad-spectrum antibiotics are administered intravenously. We use amoxicillin with clavulanic acid or a fluoroquinolone depending on the patient's associated risk factors. Pain management is provided during 2 to 3 days of hospitalization. Daily wound care is applied by the injection of a mixture of normal saline and iodine solution in the corrugated drains, followed by normal saline irrigation. The drain is mobilized exteriorly 1 to 2 $\mathrm{cm}$ each day starting from the second postoperative day and depending on the secretions. The previously described points are continued at home with a trained nurse whenever the infection is controlled and the patient is ready for discharge. After complete removal of the drains, open wounds at their corresponding sites are left to heal by secondary intention. A close follow up is necessary to examine the healing wounds and to adapt the antibiotics when necessary. The non-absorbable skin sutures are removed 7 to 10 days after the procedure. If

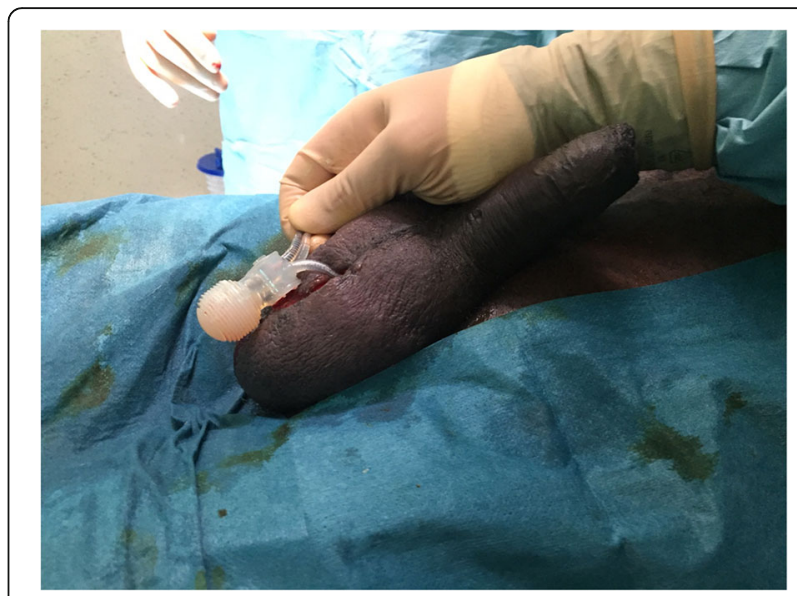

Fig. 2 Extraction of the pump is done after incising the scrotum over it

distant re-implantation is anticipated, it is best done 2 to 3 months after the resolution of the infection, and the patient is given tadalafil $5 \mathrm{mg}$ daily until the procedure.

We think that avoiding the bigger incision needed to remove all the components through the peno-scrotal incision leads to an easier reimplantation procedure, however we did not study the re-implantation results in our patients.

\section{Results}

The duration of the surgery ranged between 35 and 48 min with a mean of $41 \mathrm{~min}$. All procedures were completed successfully with a smooth course. None of the patients had any residual component of the IPP at the end of the surgery. Neither complications (urethral or intestinal injury) nor excessive bleeding (>100 mL) were documented in all patients (Table 3). No significant more pain due to multiple incisions with this technique was reported by our patients.

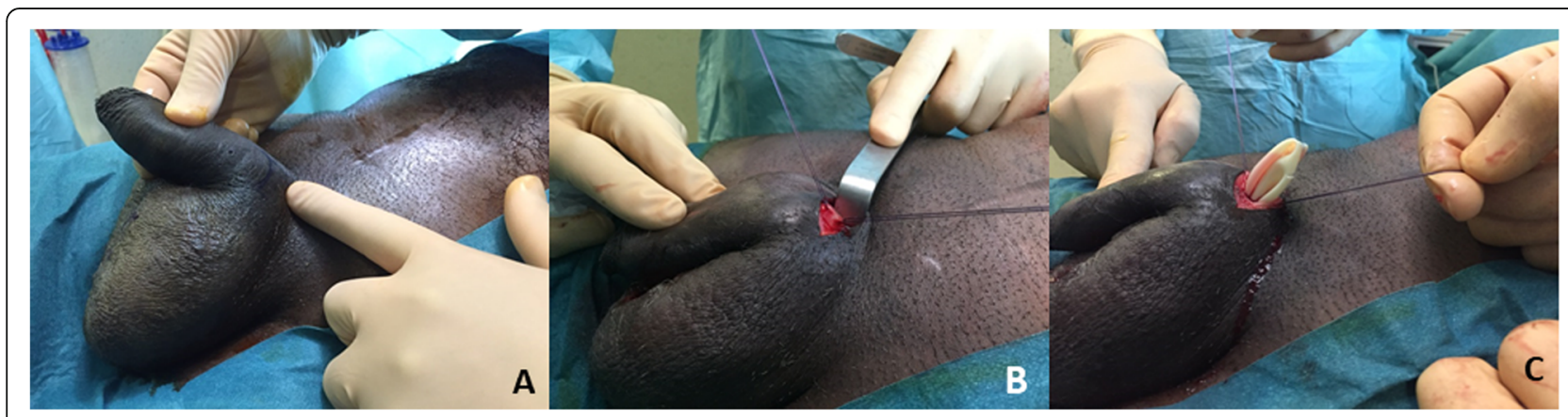

Fig. 1 a- The incisional line drawn by a sterile surgical marker at the base of the penis. b- Stay suture on each side of corporotomy. c- The proximal part of the cylinder is delivered manually 


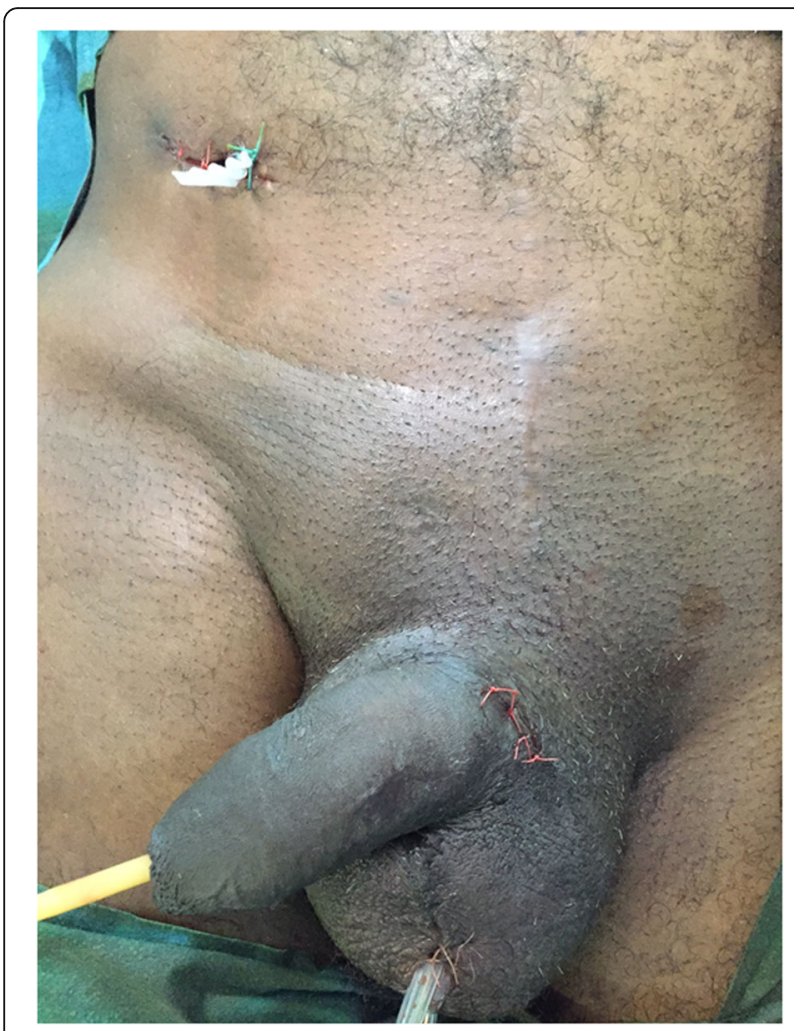

Fig. 3 The final result of the procedure: the removal of the reservoir by an inguinal incision and the placement of a corrugated silicone sheet drain inside the inguinal and scrotal incisions that are fixed to the skin

\section{Discussion}

Since the first IPP implantation described in 1973 by Scott et al., [5] many surgical techniques and devices have been described, progressively increasing patients' safety and satisfaction [6]. Complications occur more commonly in patients with diabetes, spinal cord injury or immunosuppression [7].

After reviewing the English and French literature we found two papers describing techniques of IPP removal. Oesterling et al. described in 1989 the transurethral removal of eroded malleable prosthesis. After bringing its distal end into the fossa navicularis, the prosthesis is

Table 3 Outcomes of the described procedure

\begin{tabular}{ll}
\hline Technical details & Minutes \\
\hline Minimum duration of the procedure & 35 \\
Maximum duration of the procedure & 48 \\
Complications & $\mathbf{N}$ \\
Residual component of the IPP & 0 \\
Urethral injury & 0 \\
Bleeding $>100 \mathrm{ml}$ & 0 \\
\hline
\end{tabular}

extracted through a transurethral incision of the corpora cavernosa [8]. Staller et al. published in 2016 the first article on the removal technique of infected IPP. The corporal cylinders and the pump were removed through a penoscrotal incision, while the reservoir was extracted using laparoscopic camera and instruments introduced through the same incision [9]. The transurethral removal is inappropriate in the case of infected IPP, because the healing of the iatrogenic caverno-urethral fistula will be impaired [10]. The endoscopic removal of the reservoir requires special skills for the use of the specific laparoscopic instruments and the three-dimensional spatial orientation, which are limitations in urgent septic cases that may be handled by junior urologists or surgeons with no or limited endoscopic experience. The classical penoscrotal incision is widely performed for the explantation of IPP. This approach offers great exposure and avoids dorsal nerve injury [11]. However, it carries a risk of iatrogenic urethral injury and makes the removal of the reservoir challenging in some cases. The local generated inflammatory response, the disruption of the surrounding tissues and change in the anatomical structures may predispose to fibrosis and make future implantations more difficult [3].

As the number of IPP procedures is increasing, there is a good chance that a non-experienced urologist will encounter the removal of an infected IPP in an urgent setting. The described procedure in this paper is fast and easy to learn. Every incision provides direct access to one component of the IPP, limiting the extension of the fibrosis and avoiding the centrally positioned urethra. It's ideal for residents and junior urologists with little experience in andrology to manage infected IPP in urgent situations. Undoubtedly, the penoscrotal approach is advantageous when salvage re-implantation is considered since it offers better exposure of the corpora cavernosa.

\section{Conclusion}

Our approach provides direct exposure of all components of the IPP. It reduces the risk of iatrogenic injury to the urethra and the local fibrosis (which is greater with the penoscrotal incision) that may impair future insertion of IPP. It is simple, safe, reproducible and easy to be performed by junior or unexperienced urologists in urgent cases. Further data and studies are required before the application of this technique as a standard method of removal of an IPP.

\footnotetext{
Abbreviations

IPH: Implants peniens hydrauliques; ED: Erectile dysfunction; IPP: Inflatable penile prosthesis
}

Acknowledgment Not applicable. 
Availability of data and supporting materials

Not applicable.

\section{Authors' contributions}

All authors made substantial contributions to conception and design, acquisition of data and analysis and interpretation of data; Authors participated in drafting the article and revising it critically for important intellectual content. Authors gave final approval of the version to be submitted. Each author participated sufficiently in this work and takes public responsibility for appropriate portions of the content. The author(s) read and approved the final manuscript.

\section{Funding}

Authors declare no sources of funding for this article.

\section{Ethics approval and consent to participate}

Not applicable.

\section{Consent for publication}

Written informed consent was obtained from all the patients.

\section{Competing interests}

Dr. Sebastien Beley works as a consultant for Coloplast and in Advance Medical Technology companies. Otherwise, we have no conflict of interests nor financial interests to be disclosed.

\section{Author details}

'Department of Urology, Groupe hospitalier Diaconesses-Croix Saint Simon, Paris, France. ${ }^{2}$ Department of Urology and Renal Transplantation, APHP- La pitié Salpêtrière University Hospital, Paris, France. ${ }^{3}$ Department of Urology, Clinique Turin, Paris, France. ${ }^{4}$ Department of Urology, Centre Hospitalier René DUBOS, Pontoise, France.

Received: 4 February 2020 Accepted: 6 May 2020

Published online: 18 May 2020

\section{References}

1. Aytaç IA, McKinlay JB, Krane RJ. The likely worldwide increase in erectile dysfunction between 1995 and 2025 and some possible policy consequences. BJU Int. 1999;84:50-6.

2. Mulcahy JJ. Current approach to the treatment of penile implant infections. Ther Adv Urol. 2010:69-75.

3. Scherzer ND, Dick B, Gabrielson AT, Alzweri LM, Hellstrom WJG. Penile prosthesis complications: planning, prevention, and decision making. Sex Med Rev. 2019:349-59.

4. Carson CC, Mulcahy JJ, Govier FE. Efficacy, safety and patient satisfaction outcomes of the AMS $700 C X$ inflatable penile prosthesis: results of a longterm multicenter study. J Urol. 2000;164:376-80.

5. Brantley Scott F, Bradley WE, Timm GW. Management of erectile impotence use of implantable inflatable prosthesis. Urology. 1973;2:80-2.

6. Antonini G, Busetto GM, De Berardinis E, Giovannone R, Vicini P, Del Giudice $F$, et al. Minimally invasive infrapubic inflatable penile prosthesis implant for erectile dysfunction: evaluation of efficacy, satisfaction profile and complications. Int J Impot Res. 2016;28:4-8.

7. Phé V, Rouprêt M, Ferhi K, Traxer O, Haab F, Beley S. Étiologie et prise en charge de la dysfonction érectile chez le patient diabétique. Prog Urol. 2009:364-71.

8. Oesterling JE. A simple technique for removal of eroded penile prostheses J Urol. 1989;142:1538-9.

9. Staller A, Chang C, Wagenheim G, Wang R. A novel approach for removal of an inflatable penile prosthesis reservoir using laparoscopic instruments. Asian J Androl. 2017:132-4.

10. Badlani G, De Ridder D, Mettu J, Eric R. Urinary tract fistula. Campbell-walsh Urol. 11th ed. 2016.2107.

11. Dk M, Angermeir KW. Surgical approaches for penile prosthesis implantation: penoscrotal vs infrapubic. Int J Impot Res. 2003;15:134-5.

\section{Publisher's Note}

Springer Nature remains neutral with regard to jurisdictional claims in published maps and institutional affiliations.

Ready to submit your research? Choose BMC and benefit from:

- fast, convenient online submission

- thorough peer review by experienced researchers in your field

- rapid publication on acceptance

- support for research data, including large and complex data types

- gold Open Access which fosters wider collaboration and increased citations

- maximum visibility for your research: over $100 \mathrm{M}$ website views per year

At BMC, research is always in progress.

Learn more biomedcentral.com/submissions 